\title{
The food systems textbook we all have been craving!
}

Review by Heather Johnson*

Washington State University

Review of Food, Farms, and Community: Exploring Food Systems, by Lisa Chase and Vern Grubinger. (2014). Published by University of New Hampshire Press. Available as paperback and ebook; 288 pages. Publisher's website: http://www.upne.com/1611684216.html

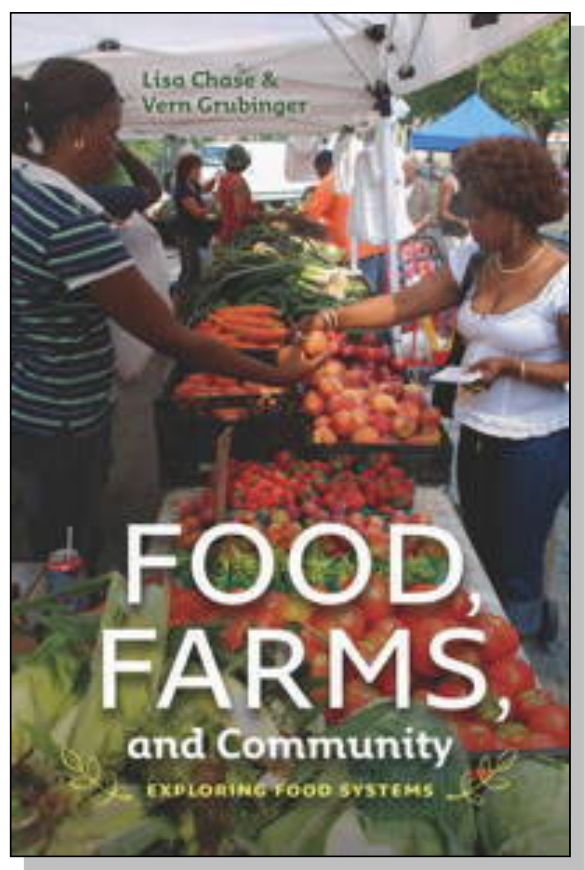

Submitted May 10, 2016 / Revised January 25, 2107 / Published online March 8, 2017

Citation: Johnson, H. (2017). The food systems textbook we have all been craving! [Book review]. Journal of Agriculture, Food Systems, and Community Development, 7(2), 153-155. http://dx.doi.org/10.5304/jafscd.2017.072.006

Copyright (C) 2017 by New Leaf Associates, Inc.

$\mathrm{N}$ atural resource specialist Lisa Chase and vegetable and berry specialist Vern Grubinger, both with University of Vermont Extension, offer an approachable introduction to

* Heather Johnson is a recent graduate of the Agricultural and Food System program at Washington State University with a double major in organic agricultural systems and agriculture and food security. She worked with the Human Development Department at WSU as an intern conducting food insecurity research in Whitman County, Washington. She is currently a Healthy Communities AmeriCorps VISTA working on food access in east Whatcom County, Washington. She plans to attend Green Mountain College for a master's in Resilient and Sustainable Communities. She can be contacted at johnson.h.m@icloud.com. food systems in Food, Farms, and Community: Exploring Food Systems. With the aim of providing a tool for educators, students, and general readers wanting to better understand our food system, Chase and Grubinger explore critical issues, provide case studies that show what is currently being accomplished, and suggest ways to further improve local food systems.

At its core, Food, Farms, and Community is a call to action for academia, farmers, policy-makers, business people, and all other stakeholders in the food system to collaborate in an informed way to help address the multitude of challenges within the modern food system. The operative word here is informed: educating readers is what the book does 
best. Where popular books and documentaries, such as The Omnivore's Dilemma and Food Inc., have increased public awareness of the scale and scope of food issues, Food, Farms, and Community delves deeply into the issues as well as some possible solutions.

While noting that food systems are complex and nonlinear, Chase and Grubinger lay out their conceptualization of the food system in a more or less linear fashion, which gives the book's structure a logical sequence. The content of Food, Farms, and Community is split between explanations of the food system and agriculture in the first few chapters, and further exploration into specific topics of concern such as agricultural labor, farm-to-school initiatives, climate change, and agritourism in later chapters. Depending on the reader's prior knowledge, the book can be approached in a linear fashion or each chapter can be read separately based on one's interest.

Chapter 1, Introduction to Food Systems, begins by describing the food system as a whole. The authors explain the food system as a web that can be viewed and analyzed from the perspective of the individual's desires. They also explain that the food system itself consists of many smaller systems, such as farming systems and social systems, as well as levels ranging from individual to global. The authors present many diagrams that clearly show how some of the smaller systems and individual perspectives work with regard to the larger food system.

The focus of chapter 2, Local Food Systems, is apropos since this is the level at which most food systems work is planned and executed. This chapter has a solid introductory explanation of the complicated definition of "local," the sociology of purchasing locally, and the response of governmental agencies and nongovernmental organizations to the increased demand for local foods. The authors are unbiased as they assert that local foods are not inherently good and emphasize the need for sustainable agriculture. At the end of the chapter the authors remind us that, important as the local food system may be, the global food system has problems that require (or demand?) solutions as well.

The authors address agribusiness in chapter 3,
The Business of Food and Farming. This chapter is necessary because by the nature of its enormous complexity and even a little purposeful marketing, it is hard to grasp the many components and transactions that make up agribusiness. Here they give a comprehensive overview of food market types, the current state of agriculture in the U.S., and the "farm-to-plate" economy. To further help the reader understand the relationship of agricultural economies to states, the authors use Vermont as a case study. The case study takes the reader on a walk-through of Vermont's agricultural economy, providing a better picture of the importance of agribusiness to states' economies.

Chapter 4, Values in Food Systems, includes topics such as consolidation, horizontal and vertical integration, and lack of transparency within the food system. The connection between nonmonetary values (externalities) and the food supply chain is discussed in a refreshingly explicit way. The authors go into just enough detail about the problems that can arise from not balancing monetary and nonmonetary values to inform the reader, while not overwhelming them. Toward the end of the chapter the authors present Shepherd's Grain and Sustainable Harvest Coffee as two examples of agricultural companies that successfully center their business around environmental and social values. This chapter also includes a "sampling" of people from the past to the present who have challenged society to change the focus of values in food systems.

The next 10 chapters address specific food system challenges, apparently chosen based on current public and academic attention. The topics are presented in a way that addresses both small and large farms, regardless of market type or geographical location; each chapter could be a stand-alone article. The chapter topics are farm labor, farming and the environment, climate change, energy, food access, farm-to-school initiatives, agritourism, food safety, beginning farmers, and conservation of farm land. I would encourage readers to pick the areas that most interest them, read those chapters first, and then read the remaining chapters. Each chapter identifies the challenges, the history of any movements around the topic, special issues, and suggestions on how to approach 
changes in that particular subject. Each topic is supported by case studies that help the reader understand real-world progress, challenges, and benefits. The case studies provide an excellent starting point for classroom discussion and thinking about what food system changes might result in improvements.

Throughout the book are scattered examples of the ways that individuals are finding solutions to particular challenges. In the final chapter, Improving Food Systems, the authors discuss ways to approach changing food systems on a larger scale. I found this to be the most valuable part of the book since it goes beyond problems and into strategic solutions. This section of the book is particularity useful to a student for two reasons, the first being that in classes there is often so much focus on identifying and understanding challenges that no time is spent discussing solutions or where to even start. Secondly, I found that as a food system student entering from the agricultural science side, this chapter gives a much-needed taste of the basic principles and strategies used to create change. For example, the authors describe strategic planning practices such as creating a positive vision statement and then creating SMART goals. The authors describe approaching food system reform with a trilevel timeframe: short-term adaption, mid-term mitigation, and long-term transformation. All three levels must be in motion at the same time, with transformation as the ultimate goal. Lastly, the authors ask the reader to think in a systems way, remembering that while working on one's particular section of the food system to be aware of the effects in other parts. Many of these terms and theories are not present in agricultural food systems curricula but would be familiar to students in other fields such as community health. Agriculture schools should take note of this inclusion, as more and more agriculture students are wanting to work in nontraditional fields such as planning and policy.

It is unrealistic to expect Food, Farms, and Community — in only 288 pages — to be a comprehensive book about as complex a subject as our food system. However, while the book provides much needed historical overviews for some aspects of the food system, such as food safety, much of the general history of our food system is left out. The authors, for example, do not mention the Green Revolution or the farm bill. I was also surprised that there is no discussion of the role of land-grant university research and extension in the food system.

Overall, food system components and challenges-often subjects that leave one a little overwhelmed and even discouraged-are presented in this book in an uplifting, almost empowering and (much needed) critical way. For the general audience, Food, Farms, and Community is a valuable resource. For educators and students such as myself the book could be a primary text or a beneficial resource for an undergraduate introductory class on food systems, if coupled with additional readings on agricultural history, landgrant universities, and agricultural science. I suspect it would be less useful in a graduate seminar or as a source of citable material. 